\title{
Distribution and growth rates of immature hawksbill turtles Eretmochelys imbricata in Fernando de Noronha, Brazil
}

\author{
Cláudio Bellini ${ }^{1}$, Armando J. B. Santos ${ }^{2}$, Ana R. Patrício ${ }^{3,4}$, Luís Felipe W. Bortolon ${ }^{2}$, \\ Brendan J. Godley ${ }^{3}$, Maria A. Marcovaldi ${ }^{5}$, Dominic Tilley ${ }^{3}$, Liliana P. Colman ${ }^{3, *}$ \\ ${ }^{1}$ Centro TAMAR-ICMBio, Natal, RN, 59160-530, Brazil \\ ${ }^{2}$ Fundação Pró-Tamar, Fernando de Noronha, PE, 53990-000, Brazil \\ ${ }^{3}$ Centre for Ecology and Conservation, University of Exeter, Cornwall Campus TR10 9EZ, UK \\ ${ }^{4}$ MARE - Marine and Environmental Science Centre, ISPA - Instituto Universitário, Lisboa, 1749-016, Portugal \\ ${ }^{5}$ Fundação Pró-Tamar, Salvador, BA, 41815-135, Brazil
}

\begin{abstract}
Knowledge of life history parameters is essential for the effective management of species of conservation concern. For migratory marine vertebrates such as hawksbill sea turtles Eretmochelys imbricata, feeding aggregations are important developmental habitats, allowing the study of population dynamics. Here, we used data from a $31 \mathrm{yr}$ mark-recapture study of juvenile hawksbill sea turtles in the Fernando de Noronha Archipelago, Brazil, to estimate key demographic parameters. Turtles recruit to the neritic habitat at similar sizes to those of other Atlantic hawksbill aggregations. The curved carapace length (CCL) at the first capture ranged from 28 to $84 \mathrm{~cm}$ (mean \pm SD: $44.6 \pm 9.8 \mathrm{~cm}$ ). Median minimum residence time of turtles captured at least twice was $3.2 \mathrm{yr}$, whilst long-term minimum residence of up to $14 \mathrm{yr}$ was also observed, with turtles showing site fidelity within the archipelago. The mean size of turtles captured was constant throughout time. Turtles grew on average $3.4 \pm 2.2 \mathrm{~cm} \mathrm{yr}^{-1}$, with a monotonic expected growth rate function generally decreasing with increasing size. At these rates, hawksbill turtles in Fernando de Noronha would need to spend ca. 14-18 yr to reach minimum adult breeding size ( $74 \mathrm{~cm} \mathrm{CCL})$. This mark-recapture study has been essential to understanding the ecology and demographic parameters of this regional hawksbill turtle neritic foraging ground.
\end{abstract}

KEY WORDS: Hawksbill turtle - Eretmochelys imbricata - Immature - Foraging grounds · Capture-mark-recapture $\cdot$ Growth rates $\cdot$ Brazil

\section{INTRODUCTION}

Migratory marine vertebrates are of conservation concern, and their effective management depends on knowledge of key demographic parameters, including recruitment, somatic growth rates, survival probabilities and abundance (Lotze et al. 2011, Mills 2013, Patrício et al. 2014, Colman et al. 2015). Aggregations allow the estimation of demographic parameters in species which disperse widely, such as seabirds (Gremillet et al. 2015), marine mammals (Calambokidis \&

${ }^{*}$ Corresponding author: 1.p.colman@exeter.ac.uk
Barlow 2004) and immature marine turtles, which form temporal aggregations in developmental habitats (Bolten 2003, Bowen et al. 2007, Casale et al. 2018). In long-lived and slow-growing marine species, longterm studies are required to inform demographic parameters and to understand population dynamics (Magurran et al. 2010). Variation in population parameters is often associated with changes in environmental conditions, with inter-specific differences in sensitivities. Ectotherms, for instance, are particularly susceptible to the surrounding environment for their

(C) The authors 2019. Open Access under Creative Commons by Attribution Licence. Use, distribution and reproduction are unrestricted. Authors and original publication must be credited. 
individual productivity (i.e. somatic growth and reproduction; Bjorndal et al. 2016), and long-term monitoring during different life stages is needed to assess population status and changes in abundance (Groom et al. 2017).

Marine turtles are long-lived and late-maturing ectothermic species with a complex life cycle, generally involving extensive migrations between breeding and foraging areas. After spending the first years of life in oceanic waters (Bolten 2003), hawksbill turtles Eretmochelys imbricata recruit to neritic habitats at a minimum size of $20 \mathrm{~cm}$ in carapace length (Bjorndal et al. 2016), using these as developmental habitats for several years (Bolten 2003). Upon approaching maturity, they begin periodic migrations between site-specific foraging grounds, breeding areas, and nesting beaches (Bowen \& Karl 2007). The immature aggregations are typically formed by mixed stocks, with contributions from several rookeries (Bjorndal et al. 2016), and thus the conditions at the development habitats, and their consequences for immature individuals, can have widespread impacts. Therefore, monitoring these aggregations informs us not only about their status, but also provides valuable information for the future of the nesting rookeries from which they originate (Bowen et al. 2007).

In the light of the current threats to marine turtles, including direct exploitation, incidental take, pollution and climate change (e.g. Daley et al. 2008, Hawkes et al. 2009, Casale \& Heppell 2016, Duncan et al. 2017), it is critical for their effective conservation to understand the roles of marine turtles in the structure and function of marine ecosystems. Investigating population dynamics is no easy task in such slow-growing and wide-dispersing species. Traditionally, the main focus of research in marine turtles has been on nesting beaches (Bjorndal 1999). Yet, long-term studies in foraging areas have contributed to our knowledge on the general foraging ecology of marine turtles (Chaloupka \& Limpus 1997, Bjorndal et al. 2000, Meylan et al. 2011), and more recent studies have focussed on patterns of recruitment, how much time turtles spend in these areas and at what age and size they are expected to reach maturity and leave those habitats (Krueger et al. 2011, Patrício et al. 2011, 2014, Bell \& Pike 2012, Colman et al. 2015, Llamas et al. 2017). There is still a need, however, for a more complete understanding of immature life stages, including population dynamics, survival rates and habitat use (Rees et al. 2016, Wildermann et al. 2018). Some of these important questions can be addressed by studying the somatic growth of individ- uals, a key parameter to assess the status of species and to understand population dynamics for both conservation and management (Omeyer et al. 2017).

The hawksbill turtle is one of the most threatened among the 7 extant marine turtle species (Mortimer \& Donnelly 2008). Hawksbill turtles play important ecological roles in coral reef habitats (León \& Bjorndal 2002, Chevis et al. 2017) and also occupy areas outside of these environments (Gaos et al. 2012), moving widely over broad geographical scales (Bjorndal et al. 2016). Studies of the somatic growth of juvenile hawksbill turtles (Diez \& van Dam 2002, Blumenthal et al. 2009b, Krueger et al. 2011, Bell \& Pike 2012, Hawkes et al. 2014) indicate that there is marked variability among populations. In the Atlantic Ocean, Caribbean hawksbill turtle nesting populations and immature aggregations were once abundant, but as overharvesting has led to their decline, some of these only exist at relictual levels today (McClenachan et al. 2006). In the southwest Atlantic Ocean, however, long-term monitoring of rookeries in northeast Brazil suggests an increase in nesting numbers in recent years (Marcovaldi et al. 2007), although there is a lack of baseline data to determine nesting levels prior to the start of the monitoring and protection activities.

In Brazil, juvenile hawksbill turtles are distributed throughout the north-northeastern coastal waters and can also be found, albeit less frequently, along the south and southeast coasts (Marcovaldi et al. 2011). Major foraging grounds are located offshore, in the Fernando de Noronha Archipelago and Atol das Rocas (Sanches \& Bellini 1999). Minor foraging grounds exist near Trindade Island, Abrolhos (Projeto TAMAR unpubl. data) and São Pedro e São Paulo Archipelagos (Proietti et al. 2012) and Arvoredo Island (Reisser et al. 2008, Proietti et al. 2012). Studies suggest that hawksbill turtles foraging at Fernando de Noronha probably originate from the northeastern Brazilian rookeries (in the states of Bahia and Rio Grande do Norte), with additional possible contributions from Caribbean and East African rookeries (Vilaça et al. 2013, Santos et al. 2019). A long-term capture-mark-recapture (CMR) study has been maintained by Projeto TAMAR (the Brazilian sea turtle conservation programme) in Fernando de Noronha since 1987 (Bellini \& Sanches 1996) to monitor the foraging aggregation, since hawksbill turtles do not nest in Fernando de Noronha. Here we consolidated this long-term dataset to (1) examine spatiotemporal variation in juvenile hawksbill somatic growth rates, (2) explore recruitment, residence time and emigration and (3) estimate time to maturity. 


\section{MATERIALS AND METHODS}

\subsection{Study area}

The volcanic offshore archipelago of Fernando de Noronha $\left(3^{\circ} 51^{\prime} \mathrm{S}, 32^{\circ} 25^{\prime} \mathrm{W}\right)$ is located $345 \mathrm{~km}$ off the northeastern coast of Brazil, and $150 \mathrm{~km}$ east of Atol das Rocas (Fig. 1). It is composed of 1 main island, Fernando de Noronha (about $9 \mathrm{~km}$ long and $2.5 \mathrm{~km}$ wide, with the major axis in the direction SW-NE) and another 18 islets, called Ilhas Secundárias or secondary islands (Almeida 2015). A national marine park (Parque Nacional Marinho, created by federal decree in 1988) encompasses part of the area, with another part of the island being designated as an environmentally protected area (created in 1986), and inhabited by around 4000 people. The climate is tropical, with 2 well-marked seasons: a rainy season from March to July and a dry season from August to February. The South Equatorial Current flows westward in the study area (Renner 2004). As a result, the western side of the archipelago is protected from the direct flow of the current, while the eastern side faces the current directly and is subjected to wave action throughout the year. During the summer (November to March) large swells are frequent and reach even the most protected bays on the western side. Tides are semi-diurnal, with an amplitude of approximately $3.2 \mathrm{~m}$ (spring tide) and $2.0 \mathrm{~m}$ (neap tide; Almeida 1955).

\subsection{Temporal patterns and field methods}

CMR data obtained between December 1987 and December 2017 were analysed; within that period, hawksbill turtles were captured in all years, although sampling of turtles was not homogeneous throughout the years, neither spatially nor temporally. Between 1987 and 1991, surveys were performed around the entire archipelago. From 1992 onwards, the surveys were performed mainly at Sueste (Fig. 1b), although the other areas in the archipelago were also frequently sampled (Colman et al. 2015). With regard to the temporal pattern of surveys, between 1992 and 2011, surveys were conducted in at least $10 \mathrm{mo} \mathrm{yr}^{-1}$, except in 2006 and 2007, when surveys were conducted for 7 and 6 mo, respectively. Between 1988 and 1991, surveys were conducted between 4 and 9 mo in each year. From 2009, surveys were conducted 12 mo in each year (Colman et al. 2015).

\subsection{Capture of turtles, tagging and measurement}

Hawksbill turtles were hand-captured by snorkelers or scuba divers at sites located around the archipelago. These places were located on both the eastern (Mar de Fora) and western (Mar de Dentro) sides of the archipelago, at depths between 0.5 and $30 \mathrm{~m}$. We classified the capture sites into 3 different regions
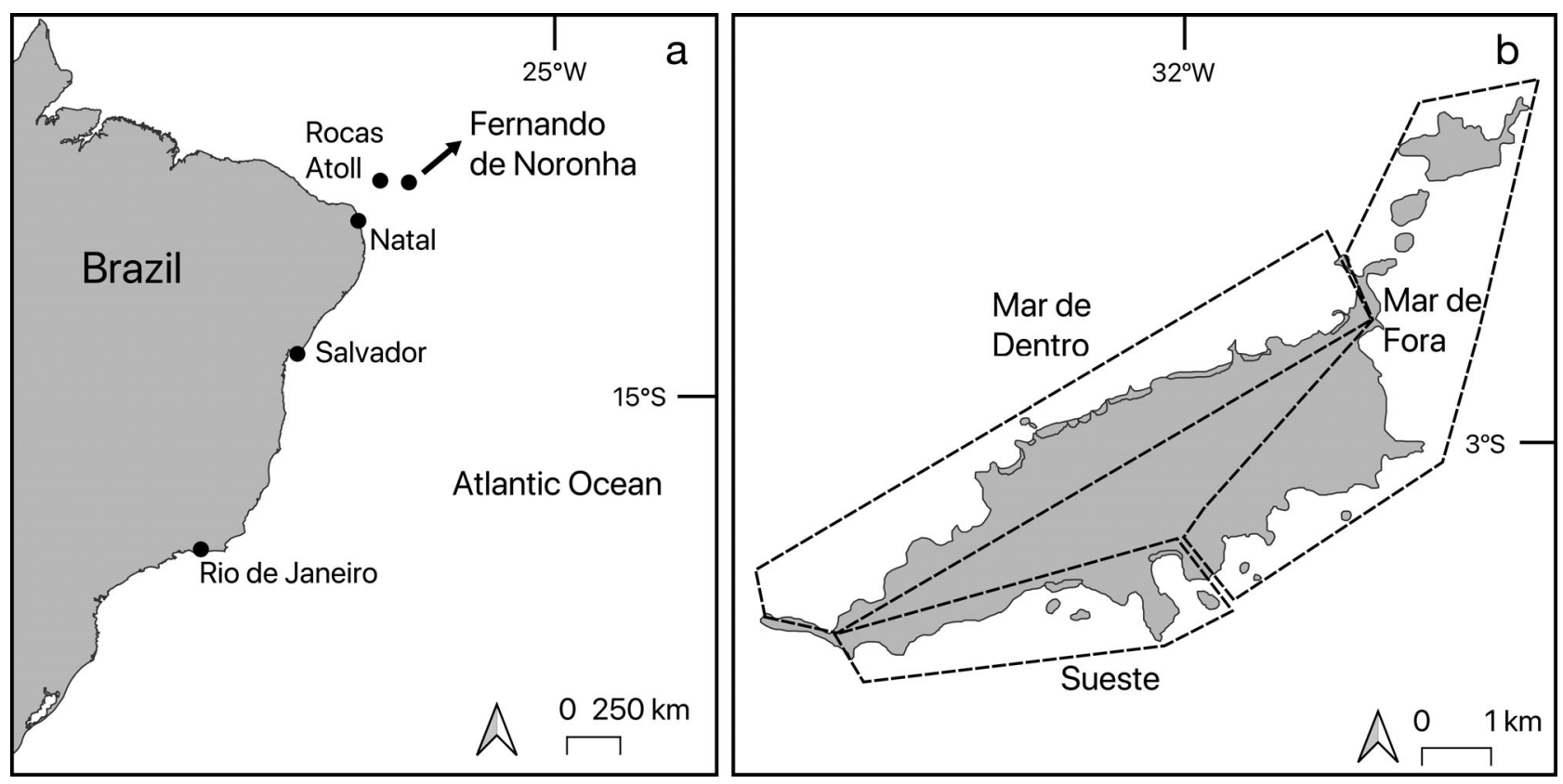

Fig. 1. (a) Location of the Fernando de Noronha Archipelago off the coast of Brazil. (b) Fernando de Noronha, indicating the 3 different regions where hawksbill turtles were captured (Sueste, Mar de Dentro and Mar de Fora) 
(Fig. 1b; Table S1 in the Supplement at www.int-res. com/articles/suppl/n040p041_supp.pdf): Mar de Fora, Mar de Dentro and Sueste, on the eastern, western and southeastern side of the archipelago, respectively. Most $(68.2 \%)$ of the hawksbill captures occurred in Sueste. This bay is located within the marine national park, has an area of approximately $0.27 \mathrm{~km}^{2}$ and a maximum depth of $5 \mathrm{~m}$. Sueste was selected as the main sampling site throughout the study period due the large number of both hawksbills and green sea turtles Chelonia mydas inhabiting the bay, and also due to the optimal conditions for snorkelling throughout the year. Despite being located on the eastern side of the main island, the bay is quite protected from wave action due to the relatively narrow entrance and the presence of 2 small islands in front of the bay entrance. As the hard bottom in the shallowest parts of the bay is exposed during low tides, most of the turtle sampling at Sueste occurred during the high tide period (from $2 \mathrm{~h}$ prior to $2 \mathrm{~h}$ after high tide).

Captured turtles were brought to the beach or boat by the snorkelers. Each captured turtle was doubletagged (1 tag on the trailing edge of each fore flipper), with Monel tags until 1994 and Inconel tags from 1995 onwards (tag style 681, National Band and Tag). The change from Monel to Inconel tags was due to the higher rate of loss of Monel tags compared to Inconel tags for hawksbill turtles in Fernando de Noronha (Bellini et al. 2001). Curved carapace length (CCL) was measured with a flexible plastic measuring tape (accuracy $=0.1 \mathrm{~cm}$ ) from the anterior point at midline (nuchal scute) to the posterior tip of the supracaudal scutes (Marcovaldi \& Marcovaldi 1999).

\subsection{Data analysis}

Only the first capture of a given individual was used to analyse the size distribution of turtles. The sex of the captured turtles was not determined, as the majority of individuals were immature and presented no external sexual dimorphism. Adult-sized turtles (i.e. $\mathrm{CCL}>75 \mathrm{~cm} ; \mathrm{n}=15$ ) were captured on a few occasions throughout the study period. Only 3 individuals were identified as males. One was captured once (68 cm CCL) and never seen again; the other 2 were caught as juveniles and had developed adult male traits, i.e. a long tail and elongated curved claws at the front flippers, when they were recaptured at 70 and $79 \mathrm{~cm} \mathrm{CCL}$, respectively. Those individuals were still considered in the analyses. The size of last capture was calculated for recaptured turtles at Sueste only ( $\mathrm{n}=99)$, since this site has maintained the most consistent capture effort throughout the years. Possible differences in the size of turtles among sites were tested with a nonparametric Kruskal-Wallis test (Hollander \& Wolfe 1999). Annual variation in CCL was assessed using a generalized additive model (GAM), within the R-package 'mgcv' (Wood 2017); for each individual, only the first record in each year was considered in the analysis $(\mathrm{n}=$ 1201).

The minimum time of residency was assumed to be the time interval in years between the first and last captures of a given individual. It is possible, however, that individual turtles might have left the area and returned, while we assumed they were there during the entire period between the first and last captures.

Growth rates were calculated for each individual

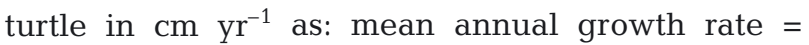
$(\Delta \mathrm{CCL} / \Delta t) \times 365$, where $\Delta \mathrm{CCL}$ is the change in CCL between captures and $\Delta t$ is the time in days since the previous capture (Colman et al. 2015). The minimum recapture interval for growth rate computation was defined to be $146 \mathrm{~d}(\sim 5 \mathrm{mo})$ to minimize measurement errors in growth estimation, as recommended by Bjorndal et al. (2016). Maximum recapture intervals were set to $4.6 \mathrm{yr}$, as very long intervals tend to diverge from the linear growth assumed here between capture and subsequent recapture (Casale et al. 2009).

Sampling design was mixed-longitudinal: through time and with partial replacement. A generalized additive mixed model (GAMM; Hastie \& Tibshirani 1990) was used to model somatic growth, by means of the R-packages 'mgcv' (Wood 2017) and 'nlme' (Pinheiro et al. 2018). Growth rate (the response variable) was determined as a function of the following covariates or predictors: mean size, mean sampling year, recapture interval and site. Turtle ID was added as a random variable, to account for unobserved heterogeneity or correlation between observations inherent to mixed longitudinal data sets (Chaloupka \& Balazs 2005). The average CCL between 2 subsequent recaptures of an individual (after the minimum recapture interval of $146 \mathrm{~d}$ ) was considered as its mean size, as it is believed that this midpoint provides a better estimation of the size of the turtle during the period for which the growth rate is being calculated (Limpus \& Chaloupka 1997, Casale et al. 2009, Colman et al. 2015). Similarly, the arithmetic mean between the years of capture and subsequent recapture was used to determine the mean sampling year. Recapture intervals were included as covariates to account for potential bias from variable recapture 
interval durations, especially with longer intervals, which possibly could lead to deviations in the linear growth (Casale et al. 2009). Numerical integrations of the expected size-specific growth rate function and $95 \%$ confidence intervals extracted from the GAMM provided the estimated time in years for a turtle to grow from a recruitment size of ca. $30 \mathrm{~cm}$ CCL until the minimum size at maturity for the species in Brazil (74 $\mathrm{cm}$; Projeto TAMAR unpubl. data). The integration was conducted using the equation: $y\left(\mathrm{CCL}_{i}\right)=$ $y\left(\mathrm{CCL}_{i-1}\right)+\left(\mathrm{CCL}_{i}-\mathrm{CCL}_{i-1}\right) / r\left(\mathrm{CCL}_{i}\right)$, where $y$ is the number of years at large since recruitment, $\mathrm{CCL}_{i}$ is the curved carapace length to which the years at large relate, $\mathrm{CCL}_{i-1}$ is the previous CCL value, and $r$ is the growth rate derived from the GAMM (Colman et al. 2015). Statistical analyses were conducted using R 3.5.1 (R Core Team 2018), and we used a significance level of $\alpha=0.05$.

\section{RESULTS}

\subsection{Capture of turtles and size distribution}

From 1987 to 2017 ( $\mathrm{n}=31 \mathrm{yr}), 514$ individual hawksbill turtles were captured in a total of 2468 capture events. Of those, 268 turtles $(52.0 \%)$ were recaptured between $1(n=91)$ and $105(n=1)$ times (Fig. 2). CCL at first capture ranged from 28 to $84 \mathrm{~cm}$ (mean \pm SD: $44.6 \pm 9.8 \mathrm{~cm}$, median $43.0 \mathrm{~cm}, \mathrm{n}=503$, as 11 individual turtles were not measured; Fig. 3a). The CCL at first capture for turtles in Sueste ranged from 28 to $80 \mathrm{~cm}$ (mean $46.6 \pm 12.4 \mathrm{~cm}, \mathrm{n}=132$ ). The average CCL of turtles on their last sighting at Sueste was $63.8 \pm 10 \mathrm{~cm}(\mathrm{n}=99$, Fig. 3b). Estimates are shown as mean $\pm \mathrm{SD}$, unless stated otherwise.

\subsection{Spatial and temporal distribution}

There was a significant difference in the size of the turtles on their first capture among the 3 sites (Kruskal-Wallis test, $\mathrm{p}<0.001, \mathrm{n}=493$ because the location of capture was not recorded for 10 individuals). A post hoc Kruskal-Wallis multiple comparisons test showed that mean size at Sueste $(46.6 \pm 12.4 \mathrm{~cm}, \mathrm{n}=$ 132) was not significantly different from that at Mar de Fora $(45.7 \pm 8.4 \mathrm{~cm}$, $\mathrm{n}=198)$, while mean size at Mar de Dentro $(41.4 \pm 7.9 \mathrm{~cm}, \mathrm{n}=163)$ was sig- nificantly smaller than at Sueste and Mar de Fora. The GAM of CCL indicated that year had no significant effect on mean turtle size at all sites across the 31 years $(F=4.52, \mathrm{p}=0.19, \mathrm{n}=1201$; Fig. 4$)$. No hawksbills were found in Fernando de Noronha bearing tags applied elsewhere. The time interval between the first and last capture ranged between $2 \mathrm{~d}$ and $14 \mathrm{yr}$ (mean \pm SD $3.9 \pm 3.0 \mathrm{yr}$, median $3.2 \mathrm{yr}, \mathrm{n}=268$ ). The individual that had the time interval between the first and last capture of $14 \mathrm{yr}$ was captured 28 times between 2002 and 2016, always at Sueste. The maximum number of captures for an individual was 105 (Fig. 2), for a turtle captured at Sueste between 1992 and 1999 (time interval between the first and last captures was $7.6 \mathrm{yr})$. Individuals recaptured at least once outside the location of first capture accounted for $10.1 \%$ of all individuals recaptured $(\mathrm{n}=268)$.

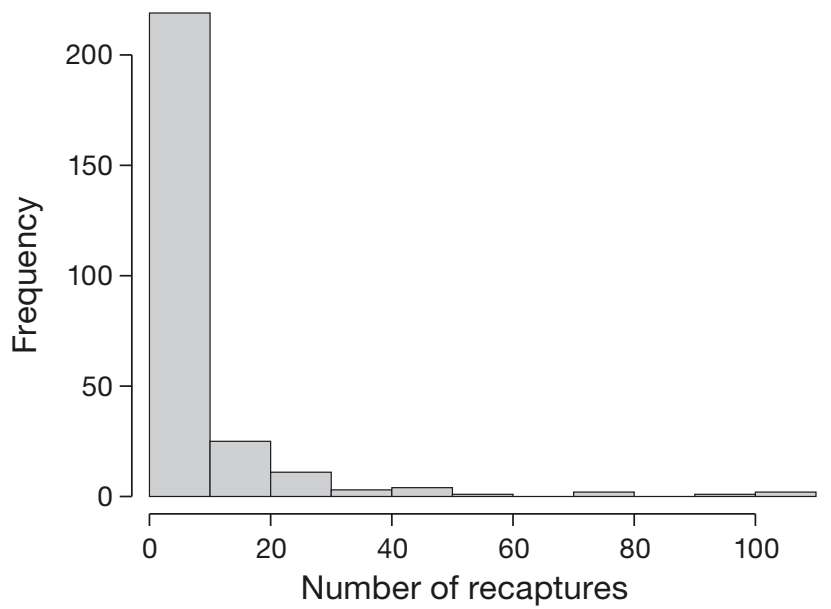

Fig. 2. Recapture frequencies of juvenile hawksbill turtles in Fernando de Noronha, Brazil, for turtles recaptured between 1987 and $2017(\mathrm{n}=268)$
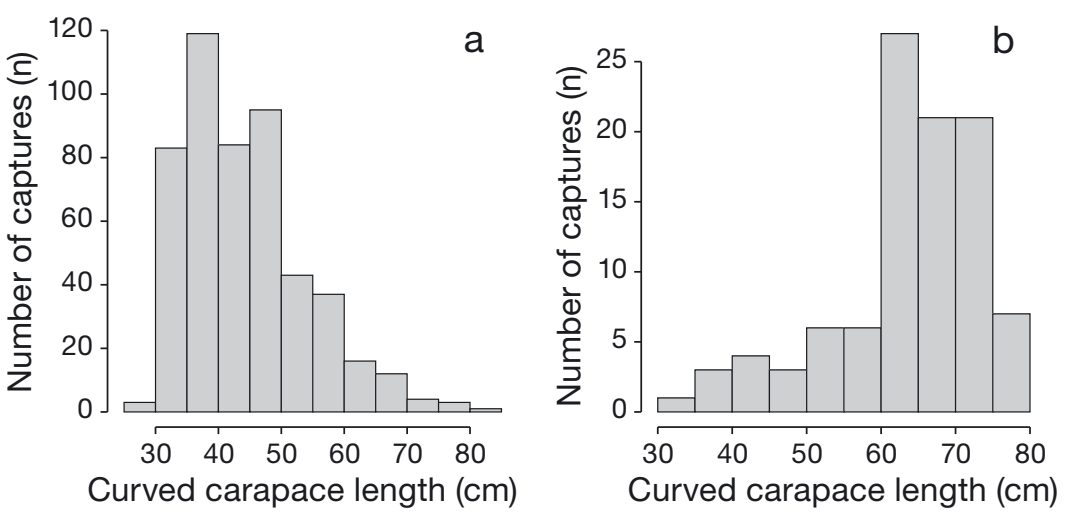

Fig. 3. Juvenile hawksbill turtles in Fernando de Noronha, Brazil, across 31 yr (1987-2017). (a) Overall curved carapace length (CCL) at first capture for all sites within the island $(\mathrm{n}=503)$ and $(\mathrm{b})$ CCL on last sighting for turtles at Sueste $(n=99)$. The CCL at first capture for turtles in Sueste ranged from 28 to $80 \mathrm{~cm}($ mean \pm SD: $46.6 \pm 12.4 \mathrm{~cm}, \mathrm{n}=132)$ 


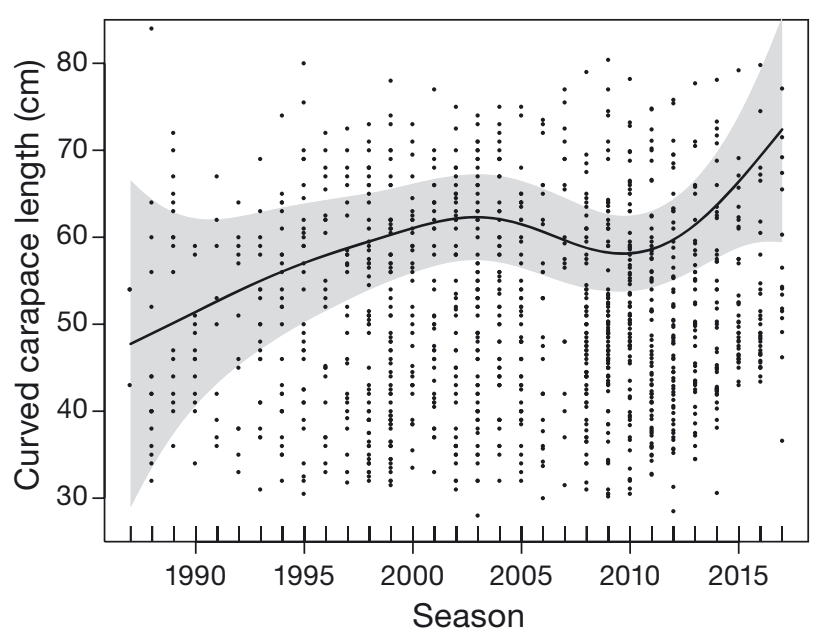

Fig. 4. Generalized additive model fit for curved carapace length (CCL) of juvenile hawksbill turtles in Fernando de Noronha, Brazil, between 1987 and 2017 (n = 1201). For each individual (represented by dots), only the first record in each year was considered in the analysis. Grey shaded area: $95 \%$ confidence interval
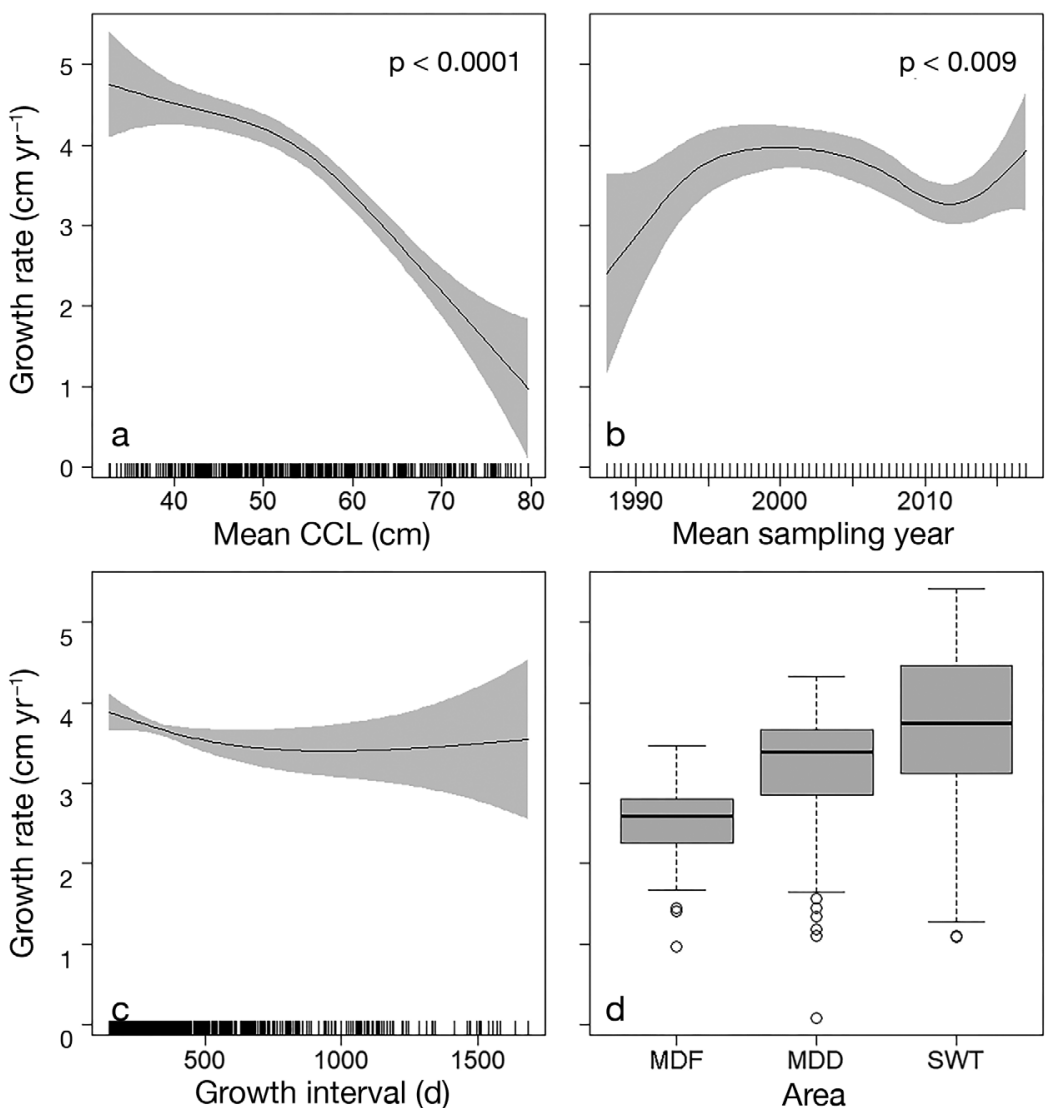

Fig. 5. Generalized additive mixed model fits for growth rates of juvenile hawksbill turtles in Fernando de Noronha, Brazil, between 1987 and 2017 ( $\mathrm{n}=793$ ). Covariates are shown on the $x$-axis: (a) mean curved carapace length (CCL), (b) mean sampling year, (c) recapture interval (days) and (d) area (MDF: Mar de Fora; MDD: Mar de Dentro; SWT: Sueste). The response variable (growth rate

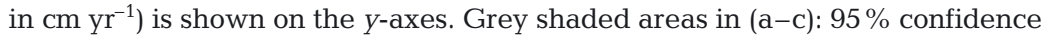
intervals. For the boxplots, boxes: first and third quartiles; whiskers: $95 \%$ confidence intervals; black horizontal lines: median; black outlined circles: outliers

\subsection{Growth rates}

Recapture intervals considered for the growth analysis varied between $5 \mathrm{mo}$ and $4.6 \mathrm{yr}$, with a median of 0.9 yr. We recorded 793 growth increments from 227 individual turtles (268 turtles were recaptured at least once, but intervals shorter than 5 mo were not considered here). Overall, the mean growth rate for juvenile hawksbill turtles in Fernando de Noronha was $3.4 \pm 2.2 \mathrm{~cm} \mathrm{yr}^{-1}$ (range 0 to $14.5 \mathrm{~cm} \mathrm{yr}^{-1} ; \mathrm{n}=793$ ). The growth rate function was monotonic, with the highest growth rates for the $30-40 \mathrm{~cm}$ CCL size class (Fig. 5, Table 1). The GAMM of growth rates indicated that size, site and mean sampling year significantly affected somatic growth, while the recapture interval had no significant effect on growth (Fig. 5). The growth rate decreased with increasing size, and growth rates were not significantly different between Mar de Dentro and Sueste, but the growth rates at both of those sites were significantly higher than Mar de Fora. The model explained $17.8 \%$ of the variance, suggesting that there is significant variability in the growth data that is not attributable to the modelled covariates. The GAMM results for each site are shown in Fig. S1. Considering the CCL classes, smaller turtles $(\sim 30 \mathrm{~cm})$ had higher growth rates than larger turtles $(\sim 70 \mathrm{~cm}$, Table 1).

\subsection{Estimated time to maturity}

From the numerical integration of the size-specific growth rate function, we obtained estimates of the expected time in years necessary for a typical hawksbill turtle in Fernando de Noronha to grow from ca. $30 \mathrm{~cm}$ to $74 \mathrm{~cm}$ $\mathrm{CCL}$, the minimum size found among nesting females in Brazil (Projeto TAMAR unpubl. data), which was ca. 13 yr (95\% CI: 12-14 yr, Fig. 6). We also estimated the expected time in years necessary for a hawksbill turtle to grow from ca. $30 \mathrm{~cm}$ to $80.5 \mathrm{~cm}$, i.e. the size of the largest hawksbill recorded among all individuals recaptured in Fernando de Noronha, not considering transients or turtles that were never recaptured, to be ca. $16 \mathrm{yr}$ (95\% CI: $14-20$ yr). 
Table 1. Growth rates of juvenile hawksbill turtles in Fernando de Noronha, 1987-2017, according to foraging area (site), life stage and size (curved carapace length, CCL) class. The life stage and size class values are for all 3 sites combined. MDD: Mar de Dentro; MDF: Mar de Fora; SWT: Sueste (see Fig. 1). Juvenile: $30-59 \mathrm{~cm}$; subadult: $60-70 \mathrm{~cm}$ CCL

\begin{tabular}{|c|c|c|c|}
\hline \multirow[t]{2}{*}{ Parameter } & \multicolumn{2}{|c|}{ Growth rate $\left(\mathrm{cm} \mathrm{yr}^{-1}\right)$} & \multirow[t]{2}{*}{$\mathrm{n}$} \\
\hline & Mean & $\mathrm{SD}$ & \\
\hline \multicolumn{4}{|l|}{ Site } \\
\hline SWT & 3.7 & 2.3 & 507 \\
\hline MDD & 3.4 & 2.1 & 164 \\
\hline MDF & 2.5 & 1.7 & 122 \\
\hline Overall & 3.4 & 2.2 & 793 \\
\hline \multicolumn{4}{|l|}{ Life stage } \\
\hline Juvenile & 3.8 & 2.2 & 528 \\
\hline Subadult & 2.7 & 1.9 & 265 \\
\hline \multicolumn{4}{|c|}{ Size class (cm) } \\
\hline 30 & 4.0 & 2.7 & 63 \\
\hline 40 & 3.7 & 2.1 & 235 \\
\hline 50 & 3.8 & 2.3 & 229 \\
\hline 60 & 3.0 & 1.9 & 198 \\
\hline 70 & 1.9 & 1.6 & 68 \\
\hline
\end{tabular}

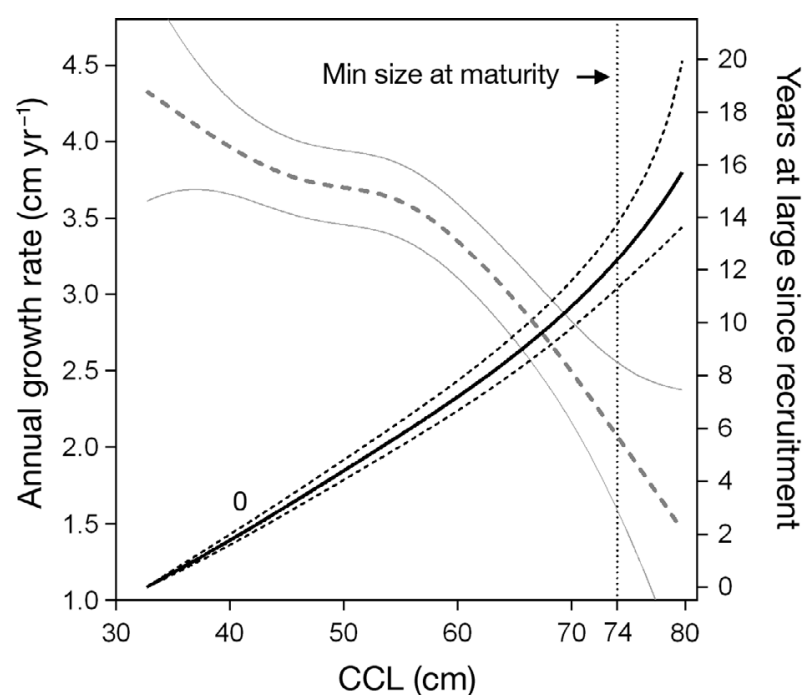

Fig. 6. Expected size-specific growth rate function (grey dashed line) within 95\% confidence intervals (solid grey lines) for hawksbill sea turtles at Fernando de Noronha, Brazil, and derived expected size-at-age function (black solid line) within $95 \%$ confidence intervals (black dashed lines), where age is in years at large since recruitment, as the age of recruits is unknown. CCL: curved carapace length

\section{DISCUSSION}

This long-term monitoring study provided invaluable information on demographic parameters of immature hawksbill turtles at an important developmental habitat for the species in the southwest
Atlantic Ocean. We detected site fidelity within the archipelago, and our estimates of growth rates enabled us to determine the potential range of time needed to reach maturity.

\subsection{Recruitment and time interval between first and last captures}

Hawksbill turtle recruits (turtles with the smallest sizes) in Fernando de Noronha moved to neritic habitats at similar sizes (25-35 cm CCL) as those reported for other Atlantic hawksbill aggregations in Brazil (20-30 cm CCL; Proietti et al. 2012), Ascension Island (minimum $33 \mathrm{~cm}$ CCL; Weber et al. 2017) and in the Caribbean (20-35 cm carapace length; Bjorndal \& Bolten 2010). The 30-50 cm CCL size class was also the most frequent size class among other hawksbill turtle juvenile aggregations in Brazil (Proietti et al. 2012). The median time between first and last captures of $3.2 \mathrm{yr}$ indicates that Fernando de Noronha is a long-term developmental habitat for hawksbill turtles, and the consistent mean size of captured turtles across years suggests that this population experiences constant rates of immigration by smaller individuals (recruits) and emigration by larger turtles (adults or large subadults).

\subsection{Growth rates}

Some turtles exhibited site fidelity within the archipelago, with some significant differences in the size and growth rates of turtles among sites. Causes for spatial variability in growth rates could include factors such as size and sex (Boulon \& Frazer 1990, Chaloupka \& Limpus 1997), environmental factors such as food quality and abundance, resource competition and predator pressure (León \& Bjorndal 2002), or abiotic factors such as water temperature, salinity, pH and turbidity, which could alter behavioural time budgets or metabolic rates and consequently influence growth rates (Diez \& van Dam 2002). The higher growth rates observed at Sueste for both green (Colman et al. 2015) and hawksbill turtles (present study) could possibly be explained by the ecological characteristics of this bay. Its sheltered, shallow and warm waters could create a more suitable habitat for turtles. The east-facing waters of Mar de Fora have higher turbulence than Mar de Dentro (Matheus et al. 2019) and are more exposed to currents, which could mean consuming more energy to access resources. The existence of distinct benthic reef assemblages within 
the Fernando de Noronha Archipelago (Matheus et al. 2019) could influence the different growth rates observed, since immature hawksbills are believed to have diets dominated by sponges and other benthic invertebrates (Krueger et al. 2011, Bjorndal et al. 2016). Further studies investigating hawksbill turtle feeding ecology and resource availability would be valuable to better understand the spatial variability of growth rates within the archipelago. It is also noteworthy that it appears that growth rate was differently affected in turtles at Mar de Dentro (positive) than at the other 2 locations (negative; Fig. S1). Additionally, the average size of turtles at Mar de Dentro is less than at the other 2 locations. We hypothesise that Mar de Dentro could be an early recruitment area, where turtles are still recovering from the oceanic phase before they start growing (Bjorndal et al. 2016). It is also possible that the small sample size for the larger size classes at Mar de Dentro (Table S2) could have influenced our results, with a few fast-growing large individuals driving the results seen in Fig. S1.

Tag recoveries from long-range movements recorded for 4 immature turtles from this population estimated similar mean growth rates (Santos et al. 2019). Somatic growth rates for hawksbill turtles in Fernando de Noronha were in the lower range of those reported in a pan-Atlantic study conducted with data from 24 sites, including our study site for the period of 1988-2013, with a general tendency towards decreasing growth rates from the north to the south Atlantic (Bjorndal et al. 2016). Ecological regime shifts caused by large-scale climatic events operating in the West Atlantic Ocean were suggested to have been driving declines in growth rates of marine turtles throughout the region and across trophic levels (Bjorndal et al. 2017). A decline in mean growth rates during the period 1997-2013 was also detected in Fernando de Noronha, although more recent data from 2014-2017, outside of the period analysed by Bjorndal et al. (2016), suggests possibly increasing growth rates during the last 5 yr (see Fig. 5b), providing critical new information given the reversal of the growth trajectory. Future studies considering the relationship between climate indices and growth dynamics would be valuable to better understand the long-term temporal pattern in the annual mean growth rates of the Fernando de Noronha aggregation, and the possible effects of climate change on hawksbill turtle productivity (Bjorndal et al. 2016). The tendency towards slower growth rates with increasing carapace length observed here was also reported in other hawksbill turtle aggregations (Blumenthal et al. 2009b, Krueger et al. 2011,
Bell \& Pike 2012, Hawkes et al. 2014) and other species with neritic juvenile life stages (e.g. green turtles; Chaloupka et al. 2004, Patrício et al. 2014).

\subsection{Estimated time needed to reach maturity}

Assuming that hawksbill turtles would live around 2-4 yr before recruiting to neritic habitats, considering age and growth estimates from skeletochronology (Snover et al. 2013) and the recruitment size in Fernando de Noronha (25-35 cm CCL), it would take approximately 14 to $18 \mathrm{yr}$ for an individual in Fernando de Noronha to reach $74 \mathrm{~cm} \mathrm{CCL}$, the minimum size of nesting hawksbill turtles in Rio Grande do Norte, Brazil (Projeto TAMAR unpubl. data). This estimate is in accordance with the probable age at maturity suggested for Pacific hawksbill turtles, between 17 and $22 \mathrm{yr}$, assuming adult size to be reached at $78.6 \mathrm{~cm}$ CCL (Snover et al. 2013). Elsewhere in the Atlantic, hawksbill turtles as small as $65.7 \mathrm{~cm}$ CCL were recorded nesting in Nicaragua (Witzell 1983; straight carapace lengths were converted to CCLs using the formula of Teas 1993). However, some individuals above the minimum adult CCL can still be immature (Meylan et al. 2011). The mean CCL at last sighting in Fernando de Noronha (with data from Sueste only) was $63.8 \mathrm{~cm}$, although some turtles have remained within the island region until up to $80.5 \mathrm{~cm} \mathrm{CCL}$, indicating that they may emigrate at different sizes. Although causes for variance in growth rates are not completely understood, in Atlantic green turtles this variance was shown to be related to differential emigration sizes (Bjorndal et al. 2019).

\subsection{Possible origin of hawksbill turtles in Fernando de Noronha}

Little is known about the possible destination areas of hawksbill turtles when they leave Fernando de Noronha. Two individuals were recaptured by fishermen in Central Western Africa (Gabon and Equatorial Guinea), located about $4600 \mathrm{~km}$ from Fernando de Noronha (Bellini et al. 2000, Grossman et al. 2007), and 3 turtles were recovered dead along the coast of Brazil, in Ceará, Rio Grande do Norte and Espírito Santo (Santos et al. 2019). Fernando de Noronha is located in the confluence of 2 oceanic currents: the North Brazilian Current and the South Equatorial Current, which may contribute to the high number of haplotypes found in this feeding aggrega- 
tion (Vilaça et al. 2013). Juvenile hawksbill turtle populations in foraging areas in the Caribbean are mostly composed of turtles from multiple rookeries, located up to $7000 \mathrm{~km}$ away from the foraging areas (Bass 1999, Bowen et al. 2007). In the Atlantic, nesting sites other than the Brazilian ones exist within that range in the Caribbean, at least $2500 \mathrm{~km}$ away (Mortimer 2008), and in São Tomé and Príncipe in Western Africa, about $4400 \mathrm{~km}$ away (MonzónArgüello et al. 2011); other relevant nesting sites might exist in the Eastern Atlantic (Monzón-Argüello et al. 2010). A characteristic of marine turtle juvenile aggregations is the 'many-to-many' (Bolker et al. 2007) composition of their populations, where groups of turtles in foraging areas are made up of individuals from different nesting colonies, and each nesting colony can contribute individuals to several foraging groups (Blumenthal et al. 2009a). The juvenile hawksbill turtle aggregation in Fernando de Noronha may have a range of natal origins, depending on the combination of the population size and distance of the regional nesting colonies, and patterns of dispersal (largely determined by ocean currents) of hatchlings from the nesting areas (Bowen et al. 2007, Blumenthal et al. 2009a, Leroux et al. 2012). Continued in-water CMR programmes, together with complementary satellite tracking, stable isotopes and genetic studies (Bowen et al. 2007, Allen et al. 2013, Jensen et al. 2016, Hart et al. 2017) could help to better understand population dynamics and connectivity.

\subsection{Human interactions}

Fishing activity in the archipelago is highly restricted, with small artisanal fishing vessels (using hook and lines) operating in designated areas. During the study period, 13 juvenile hawksbill turtles showed evidence of interaction with fisheries; 9 of these were found alive and 4 were found dead (the dead turtles with evidence of interaction with fisheries represent $10.8 \%$ of the total number of turtles found dead in the study period, $\mathrm{n}=37$ ). Ghost nets have been seen around Fernando de Noronha (Santos et al. 2012) and could also represent a threat to turtles there. Plastic fragments, virgin plastic pellets, nylon monofilaments and other marine debris, likely transported by ocean currents, have been found on Fernando de Noronha beaches (Ivar do Sul et al. 2009). The necropsy of 8 hawksbill turtles, with CCLs in the range of $27.5-75 \mathrm{~cm}$, revealed that 4 of them had ingested plastics. The level of human-induced hawksbill mortality is low in Fernando de Noronha, but the emergence of new threats such as pollution and climate change (Hawkes et al. 2009, Duncan et al. 2017) means they remain of conservation concern. The continued monitoring of juvenile hawksbill turtles in foraging areas with little anthropogenic influence such as Fernando de Noronha is valuable for obtaining baseline demographic parameters that could be compared with analogous parameters obtained at other sites where greater direct anthropogenic pressures exist.

\subsection{Conclusions}

This long-term mark and recapture programme has generated essential data for understanding ecology and demographic parameters (Strindberg et al. 2016), addressing a number of priority questions (Rees et al. 2016, Wildermann et al. 2018) for this aggregation and fitting into designed recovery plans (Marcovaldi et al. 2011, Roberts \& Hamann 2016). Another important outcome of this programme is raising awareness for marine turtle conservation. Tourism is the main economic activity in Fernando de Noronha, having grown considerably in recent years (Tischer et al. 2017). The environmental awareness activities developed by TAMAR in the region (da Silva et al. 2016) involve the local community and tourists. Throughout the years, hawksbill turtles in Fernando de Noronha have been seen by a range of public figures, students and tourists, and have also been featured in numerous television programmes, newspapers and magazines worldwide. These activities help to promote awareness of turtles and marine conservation.

Acknowledgements. We thank the numerous people involved in data collection over the years and the commercial diving operators in Fernando de Noronha who have collaborated with this research. We thank Dr. Luciano Soares for his help during the preparation of this manuscript. L.C. acknowledges the support of a Science Without Borders scholarship from the National Council for Scientific and Technological Development (CNPq), Brazil. Fieldwork in Brazil was carried out by Fundação Pró-TAMAR, which is among the institutions responsible for implementing conservation actions under the National Action Plan for the Conservation of Sea Turtles in Brazil - NAP ICMBio/MMA. Projeto TAMAR is officially sponsored by Petrobras. Data collection was conducted under permit 42760-11 from SISBIO (Authorization and Information System on Biodiversity). The manuscript benefited from the detailed input of 4 referees and the Editor. This research was submitted to SISBIO in Brazil (permit 42760-11) and approved by the ethical committee at the University of Exeter, UK. 


\section{LITERATURE CITED}

Allen CD, Lemons GE, Eguchi T, LeRoux RA and others (2013) Stable isotope analysis reveals migratory origin of loggerhead turtles in the Southern California Bight. Mar Ecol Prog Ser 472:275-285

Almeida FFM (1955) Geologia e petrologia do Arquipélago de Fernando de Noronha. Monografia 13. DNPM, Divisao de Geologia e Mineralogia, Rio de Janeiro

Almeida FFM (2015) Ilhas oceânicas brasileiras e suas relações com a tectônica atlântica. Terr Didat 2:3-18

Bass AL (1999) Genetic analysis to elucidate the natural history and behaviour of hawksbill turtles (Eretmochelys imbricata) in the Wider Caribbean: a review and reanalysis. Chelonian Conserv Biol 3:195-199

Bell I, Pike DA (2012) Somatic growth rates of hawksbill turtles Eretmochelys imbricata in a northern Great Barrier Reef foraging area. Mar Ecol Prog Ser 446:275-283

Bellini C, Sanches TM (1996) Reproduction and feeding of marine turtles in the Fernando de Noronha Archipelago, Brazil. Mar Turtle Newsl 74:12-13

Bellini C, Sanches TM, Formia A (2000) Hawksbill turtle tagged in Brazil captured in Gabon, Africa. Mar Turtle Newsl 87:11-12

Bellini C, Godfrey MH, Sanches TM (2001) Metal tag loss in wild juvenile hawksbill sea turtles (Eretmochelys imbricata). Herpetol Rev 32:172-174

Bjorndal KA (1999) Priorities for research in foraging habitats. In: Eckert KL, Bjorndal KA, Abreu-Grobois FA, Donnelly $M$ (eds) Research and management techniques for the conservation of sea turtles. IUCN/SSC Marine Turtle Specialist Group Publication No. 4, p 12-14

Bjorndal KA, Bolten AB (2010) Hawksbill sea turtles in seagrass pastures: success in a peripheral habitat. Mar Biol 157:135-145

Bjorndal KA, Bolten AB, Chaloupka MY (2000) Green turtle somatic growth model: evidence for density dependence. Ecol Appl 10:269-282

Bjorndal KA, Chaloupka M, Saba VS, Diez CE and others (2016) Somatic growth dynamics of West Atlantic hawksbill sea turtles: a spatio-temporal perspective. Ecosphere $7: \mathrm{e} 01279$

Bjorndal KA, Bolten AB, Chaloupka M, Saba VS and others (2017) Ecological regime shift drives declining growth rates of sea turtles throughout the West Atlantic. Glob Change Biol 23:4556-4568

Bjorndal KA, Bolten AB, Chaloupka M (2019) Green turtle somatic growth dynamics: distributional regression reveals effects of differential emigration. Mar Ecol Prog Ser 616:185-195

Blumenthal JM, Abreu-Grobois FA, Austin TJ, Broderick AC and others (2009a) Turtle groups or turtle soup: dispersal patterns of hawksbill turtles in the Caribbean. Mol Ecol 18:4841-4853

* Blumenthal JM, Austin TJ, Bell CDL, Bothwell JB and others (2009b) Ecology of hawksbill turtles, Eretmochelys imbricata, on a western Caribbean foraging ground. Chelonian Conserv Biol 8:1-10

Bolker BM, Okuyama T, Bjorndal KA, Bolten AB (2007) Incorporating multiple mixed stocks in mixed stock analysis: 'many-to-many' analyses. Mol Ecol 16:685-695

Bolten AB (2003) Variation in sea turtle life history patterns: neritic versus oceanic developmental stages. In: Lutz PL, Musick J, Wyneken J (eds) The biology of sea turtles, Vol II. CRC Press, Boca Raton, FL, pp 243-257
Boulon R, Frazer N (1990) Growth of wild juvenile Caribbean green turtles, Chelonia mydas. J Herpetol 24:441-445

Bowen BW, Karl SA (2007) Population genetics and phylogeography of sea turtles. Mol Ecol 16:4886-4907

Bowen BW, Grant WS, Hillis-Starr Z, Shaver DJ, Bjorndal KA, Bolten AB, Bass AL (2007) Mixed-stock analysis reveals the migrations of juvenile hawksbill turtles (Eretmochelys imbricata) in the Caribbean Sea. Mol Ecol 16:49-60

KCalambokidis J, Barlow J (2004) Abundance of blue and humpback whales in the eastern North Pacific estimated by capture-recapture and line-transect methods. Mar Mamm Sci 20:63-85

Casale P, Heppell SS (2016) How much sea turtle bycatch is too much? A stationary age distribution model for simulating population abundance and potential biological removal in the Mediterranean. Endang Species Res 29:239-254

Casale P, Mazaris AD, Freggi D, Vallini C, Argano R (2009) Growth rates and age at adult size of loggerhead sea turtles (Caretta caretta) in the Mediterranean Sea, estimated through capture-mark-recapture records. Sci Mar 73:589-595

* Casale P, Broderick AC, Camiñas JA, Cardona L and others (2018) Mediterranean sea turtles: current knowledge and priorities for conservation and research. Endang Species Res 36:229-267

* Chaloupka M, Balazs GH (2005) Modelling the effect of fibropapilloma disease on the somatic growth dynamics of Hawaiian green sea turtles. Mar Biol 147:1251-1260

* Chaloupka MY, Limpus CJ (1997) Robust statistical modelling of hawksbill sea turtle growth rates (southern Great Barrier Reef). Mar Ecol Prog Ser 146:1-8

Chaloupka M, Limpus C, Miller J (2004) Green turtle somatic growth dynamics in a spatially disjunct Great Barrier Reef metapopulation. Coral Reefs 23:325-335

Chevis MG, Godley BJ, Lewis JP, Jackson Lewis J, Scales KL, Graham RT (2017) Movement patterns of juvenile hawksbill turtles Eretmochelys imbricata at a Caribbean coral atoll: long-term tracking using passive acoustic telemetry. Endang Species Res 32:309-319

* Colman LP, Patricio ARC, McGowan A, Santos AJB, Marcovaldi MA, Bellini C, Godley BJ (2015) Long-term growth and survival dynamics of green turtles (Chelonia mydas) at an isolated tropical archipelago in Brazil. Mar Biol 162: 111-122

* da Silva VRF, Mitraud SF, Ferraz MLCP, Lima EHSM and others (2016) Adaptive threat management framework: integrating people and turtles. Environ Dev Sustain 18: 1541-1558

Daley B, Griggs P, Marsh H (2008) Exploiting marine wildlife in Queensland: the commercial dugong and marine turtle fisheries, 1847-1969. Aus Econ Hist Rev 48:227-265

* Diez CE, van Dam RP (2002) Habitat effect on hawksbill turtle growth rates on feeding grounds at Mona and Monito Islands, Puerto Rico. Mar Ecol Prog Ser 234:301-309

* Duncan EM, Botterell ZLR, Broderick AC, Galloway TS, Lindeque PK, Nuno A, Godley BJ (2017) A global review of marine turtle entanglement in anthropogenic debris: a baseline for further action. Endang Species Res 34:431-448

*Gaos AR, Lewison RL, Yanez IL, Wallace BP and others (2012) Shifting the life-history paradigm: discovery of novel habitat use by hawksbill turtles. Biol Lett 8:54-56

* Gremillet D, Peron C, Provost P, Lescroel A (2015) Adult and juvenile European seabirds at risk from marine plundering off West Africa. Biol Conserv 182:143-147 
Groom RA, Griffiths AD, Chaloupka M (2017) Estimating long-term trends in abundance and survival for nesting flatback turtles in Kakadu National Park, Australia. Endang Species Res 32:203-211

Grossman A, Bellini C, Fallabrino A, Formia A, Mba JM, Mba JN, Obama C (2007) Second TAMAR-tagged hawksbill recaptured in Corisco Bay, West Africa. Mar Turtle Newsl 116:26

Hart KM, Iverson AR, Benscoter AM, Fujisaki I and others (2017) Resident areas and migrations of female green turtles nesting at Buck Island Reef National Monument, St. Croix, US Virgin Islands. Endang Species Res 32:89-101

Hastie TJ, Tibshirani RJ (1990) Generalized additive models. Chapman and Hall, New York, NY

Hawkes LA, Broderick AC, Godfrey MH, Godley BJ (2009) Climate change and marine turtles. Endang Species Res $7: 137-154$

Hawkes LA, McGowan A, Broderick AC, Gore S and others (2014) High rates of growth recorded for hawksbill sea turtles in Anegada, British Virgin Islands. Ecol Evol 4: 1255-1266

Hollander M, Wolfe DA (1999) Nonparametric statistical methods, $2^{\text {nd }}$ edn. John Wiley \& Sons, New York, NY

Ivar do Sul JAI, Spengler A, Costa MF (2009) Here, there and everywhere. Small plastic fragments and pellets on beaches of Fernando de Noronha (Equatorial Western Atlantic). Mar Pollut Bull 58:1236-1238

* Jensen MP, Pilcher N, FitzSimmons NN (2016) Genetic markers provide insight on origins of immature green turtles Chelonia mydas with biased sex ratios at foraging grounds in Sabah, Malaysia. Endang Species Res 31: 191-201

* Krueger BH, Chaloupka MY, Leighton PA, Dunn JA, Horrocks JA (2011) Somatic growth rates for a hawksbill turtle population in coral reef habitat around Barbados. Mar Ecol Prog Ser 432:269-276

* León YM, Bjorndal KA (2002) Selective feeding in the hawksbill turtle, an important predator in coral reef ecosystems. Mar Ecol Prog Ser 245:249-258

Leroux RA, Dutton PH, Abreu-Grobois FA, Lagueux CJ and others (2012) Re-examination of population structure and phylogeography of hawksbill turtles in the Wider Caribbean using longer mtDNA sequences. J Hered 103: 806-820

KLimpus CJ, Chaloupka MY (1997) Nonparametric regression modelling of green sea turtle growth rates (southern Great Barrier Reef). Mar Ecol Prog Ser 149:23-34

Llamas I, Flores EE, Abrego ME, Seminoff JA and others (2017) Distribution, size range and growth rates of hawksbill turtles at a major foraging ground in the eastern Pacific Ocean. Lat Am J Aquat Res 45:597-605

K Lotze HK, Coll M, Magera AM, Ward-Paige C, Airoldi L (2011) Recovery of marine animal populations and ecosystems. Trends Ecol Evol 26:595-605

* Magurran AE, Baillie SR, Buckland ST, Dick JM and others (2010) Long-term datasets in biodiversity research and monitoring: assessing change in ecological communities through time. Trends Ecol Evol 25:574-582

Marcovaldi MA, Marcovaldi GG (1999) Marine turtles of Brazil: the history and structure of Projeto TAMARIBAMA. Biol Conserv 91:35-41

Marcovaldi MA, Lopez GG, Soares LS, Santos AJB, Bellini C, Barata PCR (2007) Fifteen years of hawksbill sea turtle (Eretmochelys imbricata) nesting in northern Brazil. Chelonian Conserv Biol 6:223-228
Marcovaldi MA, Lopez GG, Soares LS, Bellini C, Santos AJB, Lopez M (2011) Avaliação do estado de conservação da tartaruga marinha Eretmochelys imbricata (Linnaeus, 1766) no Brasil. Biodivers Bras 1:20-27. www. icmbio.gov.br/revistaeletronica/index.php/BioRR/article/ view/88

* Matheus Z, Francini-Filho RB, Pereira-Filho GH, Moraes FC, de Moura RL, Brasileiro PS, Amado-Filho MS (2019) Benthic reef assemblages of the Fernando de Noronha Archipelago, tropical Southwest Atlantic: Effects of depth, wave exposure and cross-shelf positioning. PLOS ONE 14:e0210664

*McClenachan L, Jackson JBC, Newman MJH (2006) Conservation implications of historic sea turtle nesting beach loss. Front Ecol Environ 4:290-296

* Meylan PA, Meylan AB, Gray JA (2011) The ecology and migrations of sea turtles 8 . Tests of the developmental habitat hypothesis. Bull Am Mus Nat Hist 357:1-70

Mills LS (2013) Estimating population vital rates. In: Mills S (ed) Conservation of wildlife populations: demography, genetics and management. Wiley Blackwell, Oxford, p 54-76

* Monzón-Argüello C, Rico C, Marco A, López P, LópezJurado LF (2010) Genetic characterization of eastern Atlantic hawksbill turtles at a foraging group indicates major undiscovered nesting populations in the region. J Exp Mar Biol Ecol 387:9-14

* Monzón-Argüello C, Loureiro NS, Delgado C, Marco A, Lopes JM, Gomes MG, Abreu-Grobois FA (2011) Príncipe island hawksbills: genetic isolation of an eastern Atlantic stock. J Exp Mar Biol Ecol 407:345-354

* Mortimer JA (2008) The state of the world's hawksbills. SWOT Rep 3:10-13

Mortimer JA, Donnelly M (2008) Eretmochelys imbricata. The IUCN Red List of Threatened Species 2008: e.T8005 A12881238. http://dx.doi.org/10.2305/IUCN.UK.2008. RLTS.T8005A12881238.en

Omeyer LCM, Godley BJ, Broderick AC (2017) Growth rates of adult sea turtles. Endang Species Res 34:357-371

*Patrício AR, Velez-Zuazo X, Diez CE, Van Dam R, Sabat AM (2011) Survival probability of immature green turtles in two foraging grounds at Culebra, Puerto Rico. Mar Ecol Prog Ser 440:217-227

* Patrício R, Diez CE, van Dam RP (2014) Spatial and temporal variability of immature green turtle abundance and somatic growth in Puerto Rico. Endang Species Res 23: 51-62

* Pinheiro J, Bates D, DebRoy S, Sarkar D, R Core Team (2018) nlme: linear and nonlinear mixed effects models. R package version 3.1-137. https:/CRAN.R-project.org/ package $=$ nlme

Proietti MC, Reisser J, Secchi ER (2012) Foraging by immature hawksbill sea turtles at Brazilian Islands. Mar Turtle Newsl 135:4-6

R Core Team (2018) R: a language and environment for statistical computing. R Foundation for Statistical Computing, Vienna

Rees AF, Alfaro-Shigueto J, Barata PCR, Bjorndal KA and others (2016) Are we working towards global research priorities for management and conservation of sea turtles? Endang Species Res 31:337-382

Reisser J, Proietti M, Kinas P, Sazima I (2008) Photographic identification of sea turtles: method description and validation, with an estimation of tag loss. Endang Species Res 5:73-82 
Renner S (2004) Plant dispersal across the tropical Atlantic by wind and sea currents. Int J Plant Sci 165:S23-S33

Roberts JD, Hamann M (2016) Testing a recipe for effective recovery plan design: a marine turtle case study. Endang Species Res 31:147-161

Sanches TM, Bellini C (1999) Juvenile Eretmochelys imbricata and Chelonia mydas in the Archipelago of Fernando de Noronha, Brazil. Chelonian Conserv Biol 3:308-311

Santos AJB, Bellini C, Bortolon LF, Coluchi R (2012) Ghost nets haunt the olive ridley turtle (Lepidochelys olivacea) near the Brazilian islands of Fernando de Noronha and Atol das Rocas. Herpetol Rev 43:245-246

Santos AJB, Bellini C, Bortolon LFW, Outerbridge B and others (2019) Long-range movements and growth rates of Brazilian hawksbill turtles: insights from a flipper-tagging program. Chelonian Conserv Biol 18:75-81

Snover ML, Balazs GH, Murakawa SKK, Hargrove SK, Rice MR, Seitz WA (2013) Age and growth rates of Hawaiian hawksbill turtles (Eretmochelys imbricata) using skeletochronology. Mar Biol 160:37-46

Strindberg S, Coleman RA, Burns Perez VR, Campbell CL, Majil I, Gibson J (2016) In-water assessments of sea turtles at Glover's Reef Atoll, Belize. Endang Species Res 31: 211-225

Teas WG (1993) Species composition and size class distribu-

Editorial responsibility: Paolo Casale,

Pisa, Italy tion of marine turtle strandings on the Gulf of Mexico and Southeast United States coasts, 1985-1991. NOAA Tech Memo NMFS-SEFSC 315. NOAA/NMFS, Miami, FL

* Tischer MC, de Carli RC, Silva FJL, Silva JM Jr (2017) Tourism growth altering spinner dolphins' area of occupation in Fernando de Noronha Archipelago, Brazil. Lat Am J Aquat Res 45:807-813

* Vilaça ST, Lara-Ruiz P, Marcovaldi MA, Soares LS, Santos FR (2013) Population origin and historical demography in hawksbill (Eretmochelys imbricata) feeding and nesting aggregates from Brazil. J Exp Mar Biol Ecol 446: 334-344

*Weber SB, Weber N, Godley BJ, Pelembe T, Stroud S, Williams N, Broderick AC (2017) Ascension Island as a mid-Atlantic developmental habitat for juvenile hawksbill turtles. J Mar Biol Assoc UK 97:813-820

*Wildermann NE, Gredzens C, Avens L, Barrios-Garrido HA and others (2018) Informing research priorities for immature sea turtles through expert elicitation. Endang Species Res 37:55-76

Witzell WN (1983) Synopsis of biological data on the hawksbill turtle Eretmochelys imbricata (Linnaeus, 1776). FAO Fisheries Synopsis No. 137. FAO, Rome

Wood SN (2017) Generalized additive models: an introduction with $\mathrm{R}, 2^{\text {nd }}$ edn. CRC Press, Boca Raton, FL

Submitted: January 14, 2019; Accepted: August 4, 2019 Proofs received from author(s): September 25, 2019 